\title{
腎盂腫瘍の臨床的研究
}

$\begin{array}{clllll} & \text { 菱 } & \text { 沼 } & \text { 秀 } & \text { 雄 } \\ & \text { 増 } & \text { 田 } & \text { 富士男 } \\ & \text { 佐 } & \text { 々 } & \text { 忠 } & \text { 正 } \\ \text { 東京慈患会医科大学泌尿器科学教室 } & \text { 荒 } & \text { 井 } & \text { 由 } & \text { 和 } \\ \text { (主任: 町田豊平教授) } & \text { 小 } & \text { 路 } & & \text { 良 } \\ & \text { 陳 } & & \text { 瑞 } & \text { 昌 } \\ & \text { 町 } & \text { 田 } & \text { 豊 } & \text { 平 } \\ \text { 帝京大学医学部第 } 2 \text { 病理学教室 } & \text { 小 坂 } & \text { 井 } & & \text { 守 }\end{array}$

\section{CARCINOMA OF THE RENAL PELVIS}

Hideo Hishinuma, Fujio Masuda, Tadamasa Sasaki, Yoshikasu Arai, Ryo Shoji,

Zuisho Chin and Toyohei Machida

Department of Urology, The Jikei University School of Medicine

(Director: Prof. T. Machida)

Mamoru Kozakai .

Department of Pathology, Teikyo University School of Medicine

The present paper concerns with our review on the clinical results of a total of 23 patients with tumor of the renal pelvis, who were seen at Jikei University Hospital in the 22 years' period from 1953 to 1974. Out of these 23 cases, 21 had transitional cell carcinoma and the remaining 2 had squamous cell carcinoma.

The affected side was left for 15 cases and right for 8 cases. The incidence was 6.7 times higher for male patients than for female patients. The average age of patients was 59 years.

The most frequent initial symptom was gross hematuria in 20 cases $(87 \%)$, followed by pain in 3 cases $(13 \%)$. The main symptoms were gross hematuria in 22 cases $(96 \%)$, pain in 8 cases $(35 \%)$ and palpable mass in 4 cases $(17 \%)$, in the decreasing order. Two of the 4 cases in which a palpable mass was present had squamous cell carcinoma and the remaining 2 cases had advanced hydronephrosis which resulted from associated ureteral tumor. Thus, in these 4 cases no patient was included who were with palpable mass in the presence of uncomplicated transitional cell carcinoma of the renal pelvis. Nonurologic symptoms such as gastrointestinal distrubances were seen in 8 cases $(35 \%)$.

Laboratory tests revealed anemia in 7 cases $(30 \%)$ and accelerated ESR in 10 cases $(43 \%)$. In addition, in 6 cases $(38 \%)$ an increase in $\alpha_{2}$-globulin was noted. However, in no case hepatic dysfunction or hypercalcemia was observed. Urinary cytologies carried out in 8 cases were positive for tumor cells in 3 cases $(38 \%)$.

Plain film of the kidney indicated association of renal stones in 3 cases $(13 \%)$, and soft tissue masses in 4 cases $(17 \%)$. From the findings of excretory urography, filling defect was detected in the pelvic area in 19 cases $(83 \%)$ and in 4 cases $(17 \%)$ there was no visualization. Out of 11 cases in which renal angiographic studies were carried out, in 6 cases $(55 \%)$ an encasement of renal artery was shown, while in 3 cases $(27 \%)$ an enlargement of pelviureteric artery was observed. Besides these findings, neovascularity was observed in 5 cases (45\%).

In $8(38 \%)$ out of 21 cases of transitional cell carcinoma of the renal pelvis, association of bladder and/or ureteral tumor was demonstrated. In 5 of these 8 cases, complications were found at the same 
time when tumor of the renal pelvis was seen, but in 2 other cases, complications occurred 8 months and one year and 11 months after operation of pelvic tumor, respectively. In the remaining one case, pelvic tumor was detected 5 years and 2 months after total cystectomy for tumor of the bladder.

Seventeen cases $(74 \%)$ out of 23 cases underwent nephrouretectomy and in 13 of these cases the intramural ureter was removed with cuff of bladder. In the remaining 6 cases, comprised of cases in early years and those of squamous cell carcinoma of the renal pelvis, only nephrectomy was done.

The 5-year survival rate in 21 cases of transitional cell carcinama was $60 \%$, showing close correlation of prognosis with the histological grade and stage. All the 3 cases, in which palpable mass was observed or no visualization was noted by the excretory urography, died within 5 years. These 3 cases, though classified as low grade, presented hydronephrosis resulted from ureteral tumor which complicated concurrently. From these data it seems that the prognosis of transitional cell carcinoma of the renal pelvis associated with ureteral tumor is poor.

In this series, both of 2 cases of squamous cell carcinoma died within one year.

\section{緒言}

一般に腎腫瘍といわれているもののらちで，腎孟腫瘍 は腎実質腫瘍に比してはるかに少ないものである。した がつて, 1 機関で多くの症例を対象とした詳細な検討は 少ない。われわれは, 慈恵医大附属病院に打いて, 1953 年より1974年までの 22 年間に腎盂腫瘍23例を経験したの で, その臨床的観察を行ない, あわせて文献的考察を加 えて報告する。

\section{臨床的観察}

\section{1. 発生頻度}

過去 22 年間の外来新患者数は 49,710 名, 入院患者数は 6,868名で，そのうち腎孟腫瘍と診断されたものは23名 であり，外来患者执よび入院患者に対する比率はとれぞ れ0.046\%および0.3\%であつた。またその間の全腎腫痬 患者は120名で, 腎㙉腫瘍はその19\%を占めている（表 1).なお自験例23例はすべて組織学的に腎孟腫瘍と診断 されて打り，21例は移行上皮癌，2例は扁平上皮癌であ

表 1 腎腫瘍の分類

\begin{tabular}{|c|c|c|c|}
\hline & \multicolumn{2}{|c|}{ 患 㑡 } & \multirow{2}{*}{ 計 } \\
\hline & 右 & 左 & \\
\hline 腎細胞癌 & 39 & 42 & 81 \\
\hline Wilms 腫穆 & 2 & 3 & 5 \\
\hline 腎肉腫 & 1 & 1 & 2 \\
\hline 腎血管筋脂肪腫 & 2 & 3 & 5 \\
\hline 腎血管腫 & 2 & 1 & 3 \\
\hline 孟盂移行上皮癌 & 8 & 13 & 21 \\
\hline 堅孟扁平上皮癌 & 0 & 2 & 2 \\
\hline 腎被膜腫場 & 1 & 0 & 1 \\
\hline 計 & 55 & 65 & 120 \\
\hline
\end{tabular}

つた。

2. 患側, 性別, 年路.

患側は左15例, 右 8 例で左腎に多く又られ，性別では 男子20例, 女子 3 例と男子は女子の約6.7倍であつた. 年齢は22歳の女子に発生した 1 例をのぞき，23例中22例 は40歳以上で, 60 歳台が 10 例と最も多く, 平均年齢は 59 歳であつた。また男女による年齢差はみられなかつた (表 2 ).

表 2 性別, 年令

\begin{tabular}{c|c|c|c|c|c|c|c}
\hline & $20 \sim 29$ & $30 \sim 39$ & $40 \sim 49$ & $50 \sim 59$ & $60 \sim 69$ & $70 \sim 79$ & 計 \\
\hline 今 & 0 & 0 & 4 & 6 & 8 & 2 & 20 \\
\hline \& & 1 & 0 & 0 & 0 & 2 & 0 & 3 \\
\hline 計 & 1 & 0 & 4 & 6 & 10 & 2 & 23 \\
\hline
\end{tabular}

\section{3. 初発症状}

腎腫瘍の三大症状の 1 つである肉眼的血尿が 23 例中 20 例， $87 \%$ と圧倒的に多く，ついで腎部疼痛が 3 例，13\% にみられたが，腎部腫瘤を初発症状としたものは 1 例も なかつた。腎部疼痛を初発症状とした 3 例中 1 例は同時 に肉眼的血尿を認めて招り, 疼痛のみをしめした 2 例 は，いづれも腎結石を併発していたものである。一方尿 路外の症状としては発熱, 全身供急感が各 1 例にみられ た.

\section{4. 臨床症状}

初発症状を含めた臨床症状についてみると表 3 のごと くである. 肉眼的血尿は23例中22例とほぼ全例にみられ た.湿微鏡的血尿も認められなかつた 1 例は，腎盂扁平 上皮癌であつた。疼痛は 23 例中 8 例, 35\%にみられた が, このらち 2 例は疝痛様発作であつた.この 2 例は同 
表 3 臨床症状

\begin{tabular}{|c|c|}
\hline 症 状 & 例 数 \\
\hline 血 & $22(9696)$ \\
\hline 腎 部 疼 痛 & $8(35 \%)$ \\
\hline 腎 部 腫 瘤 & $4(1796)$ \\
\hline 胃 腸 症 状 & 4 \\
\hline 発 熱 & 2 \\
\hline 体重 減少 & 2 \\
\hline 全身倦急感 & 1 \\
\hline 精索静脈瘤 & 1 \\
\hline
\end{tabular}

時に強血尿を呈しており, 凝血による尿流障害に起因す るものと思われた。腫瘤は 4 例, $17 \%$ に認められたが， このうち 2 例は腎孟扁平上皮癌であり，2 例は併発した 尿管腫瘍により高度の水腎症を生じた例で, 腎盂の移行 上皮癌のみで腎腫瘤を触知したものはなかつた，尿路外 症状は 8 例にみられたが, 胃腸症状が 4 例と最も多く, ついで発熱 2 例, 体重減少 2 例, 全身倦怠感 1 例, 精索 静脈瘤 1 例であつた。

\section{5. 臨床検査成績}

(1) 血液検查

赤血球数 $350 \times 10^{4}$ 以下, $\mathrm{Hb} 11.0 \mathrm{~g} / \mathrm{dl}$ 以下の貧血は 23 例中 7 例，30\%に認められた. 7 例中低色素性貧血は 1 例で, 2 例が正色素性, 4 例が高色素性貧血であつた。 赤血球増多症を示したものは 1 例もみられない。

（2） 赤沈

1 時間值 $30 \mathrm{~mm}$ 以上の亢進が10例, $43 \%$ にみられた. 一方 7 例は 1 時間值 $10 \mathrm{~mm}$ 以下であつた。 貧血を有する 7 例中 4 例は赤沈がえ進していた。 また血清蛋白分画と の関係をみると, 赤沈无進例では $\alpha_{2}$-globulin, $\gamma$-globulin の明らかな増加傾向がみられた。

（3）血清蛋白像

血清蛋白像は16例について検討し, albumin の減少, $\alpha_{2}$-globulin および $\gamma$-globulin の上昇傾向がみられた が, 特に $\alpha_{2}$-globulin は 6 例, $38 \%$ に上昇を示した。

(4) 肝機能検查

肝機能検査としては，16例に上述の $\alpha_{2}$-globulin と ともにフルカリフォスファターゼ, 血清ビリルビン值, プロトロンビン時間, LDH およびトランスアミラーゼ (GOT, GPT) を測定した. 16例中 LDH の上昇したも のが 2 例, GOT, GPT の上昇を示したものが 1 例, プ ロトロンビン時間の延長したものが 1 例みられた. しか
乙上記の 6 項目の検査中, 3 項目以上異常を呈したもの は 1 例もなかつた。

（5）高カルシウム血症

高カルシウム血症のみられたものは 1 例のみであつ た。本例は結石を伴なつた腎孟扁平上皮癌で, 骨への転 移の疑われた症例である。

（6） 尿路感染

3 例に尿路感染がみられたが，2 例は腎結石を伴なつ た腎盎扁平上皮癌であり，1例はカテーテル留置の施行 された例であつた。

（7） 尿中細胞診

尿中細胞診は 8 例に行ない, class Vが 1 例, class IV が 2 例と 3 例に陽性であつた。これを摘出腎の組織学的 grade によりみると, high grade (grade III, IV) は 4 例 中 2 例で, low grade (grade I, II) の 4 例中 1 例より 陽性率が高かつた。

6. X線学的検查

(1) 腹部単純撮影

腎部に結石が 3 例認められたが，そのうち 2 例は扁平 上皮癌で, 移行上皮癌は 1 例のみであつた。軟部腫瘤を 認めたものは 4 例で, 腎孟扁平上皮癌 2 例拈よび巨大な 水腎症を呈したもの 2 例であつた。

（2）腎孟造影

排泄性腎孟造影は23例全例に行ない，逆行性腎孟造影 は16例に施行した。排泄性腎孟造影での主要な所見は腎 孟腎杯の充満欠損で, 23例中19例, 83\%に認められた. のこりの 4 例は無造影であつたが，このうち 2 例は結石 を伴なら扁平上皮癌であり, 他の 2 例は同時に発生した 尿管腫瘍のため巨大水腎症を呈したものである.すなわ ち併発腫瘍のない腎盂移行上皮癌は，すべて排泄性腎孟 造影で腎盂腫瘍が疑われ，逆行性腎盂造影を行ならこと によりさらに明確になつたものである。また腎輪廓の変 化をきたしたものは 5 例，22\%で，いづれも突出がみら

表 4 腎㙉腎杯および腎輪廓の変化

\begin{tabular}{|c|c|c|c|c|c|c|c|}
\hline & \multicolumn{6}{|c|}{ 腎 輪 廊 の変 化 } \\
\hline & & 無造影 & 突 出 & 消 失 & 凹 み & 正 常 & 計 \\
\hline \multirow{5}{*}{$\begin{array}{l}\text { 腎 } \\
\text { 盎 } \\
\text { 杯 } \\
\text { の } \\
\text { 変 } \\
\text { 化 }\end{array}$} & 無 造影 & 4 & 0 & 0 & 0 & 0 & 4 \\
\hline & 王排偏位 & 0 & 0 & 0 & 0 & 0 & 0 \\
\hline & 充満欠損 & 0 & 5 & 0 & 0 & 14 & 19 \\
\hline & 正 常 & 0 & 0 & 0 & 0 & 0 & 0 \\
\hline & 計 & 4 & 5 & 0 & 0 & 14 & 23 \\
\hline
\end{tabular}


れた（表 4 )。

（3）血管造影

腎動脈造影は11例に行なつた。腎動脈の狭窄は 6 例 飞，腎孟尿管動脈の拡大は 3 例に認められた。また 6 例 に細かい不規則な異常血管をみたが，5例には血管新生 を認めず，血管瘤，動静脈瘦，寄生動脈などをみた例は なかつた（表 5 ).側副静脈は 2 例にみられ，いずれも腎 静脈の閉塞を伴なつていた。

表 5 血管造影所見（11例）

\begin{tabular}{c|c|c}
\hline \multicolumn{2}{c|}{ 所 見 } & 例 数 \\
\hline \multicolumn{2}{c}{ 血管狭窄 } & 6 \\
\hline \multirow{3}{*}{ 血管新生 } & 無 & 5 \\
\cline { 2 - 3 } & 乏 & 5 \\
\cline { 2 - 3 } & 中 高度 & 1 \\
\hline \multicolumn{2}{c}{ 腎孟尿管動脈拡大 } & 3
\end{tabular}

\section{7. 併発尿路上皮腫瘍}

腎孟移行上皮癌21例中，尿管または膀胱に移行上皮腫 瘍の発生したものは 8 例，38\%であつた。 8 例中 2 例は 尿管拉よび膀胱に，2 例は尿管に，4 例は膀脱に生じて いる. 尿管に腫瘍のみられた 4 例はすべて同側であり， 反対側の腎孟や尿管に腫瘍の認められた例は 1 例もなか つた。つぎに発生の時期よりみると，腎盂腫湯診断と同 時に認められたものは 8 例中 5 例であり， 2 例は術後 8 カ月目および 1 年11カ月目に膀胱腫瘍が発生している. また 1 例は膀胱腫瘍に対する膀脱全摘除術施行後, 5 年 2 カ月目に腎盂腫瘍が発見された。

\section{8. 治療}

23例全例に手術を施行した。腎尿管摘除術は17例に行 なつたが，このうち13例は尿管口周辺の膀脱壁の一部を 含めて摘出した． 5 例は単に腎摘除のみを行なつたが， このうち 2 例は扁平上皮癌であり， 2 例は1954年以前の 症例であり，1 例は一般状態不良の症例であつた。また 1 例は腫場の浸潤が強く, 試験開腹に終つた（表 6 ).

放射線療法を行なつたのは 6 例で, 主として術後腎部 に3.000 5.000 rads 照射している。

化学療法は18例に施行した。初期の12例は mitomycin C $2 \mathrm{mg} \times 10$ 回の投与を行なつたが，最近の 6 例は MFC 療法, すなわち mitomycin C 2mg, 5-fluorouracil 250 $\mathrm{mg}$, cytosine arabinoside $20 \mathrm{mg}$ を術直後より週 2 回, 合計10回行なつている.
表 6 腎孟移行上皮癌の手術々式

\begin{tabular}{c|c|c}
\hline 術 式 & \multicolumn{2}{|c}{ 例 数 } \\
\hline $\begin{array}{c}\text { 㹂展管摘除術 } \\
\text { 膀胱壁切除 }\end{array}$ & 13 & \multirow{2}{*}{17} \\
\hline 腎尿管摘除術 & 4 & \\
\hline 腎 摘 除 術 & 3 & \\
\hline 試 験 開 腹 & 1 \\
\hline 計 & 21 \\
\hline
\end{tabular}

\section{9. 病理学的所見}

移行上皮癌17例について，次のような基準で grade と stage を分類した。

組織学的 grade はIからIVまでに分けたが, grade I は正常粘膜の 乳頭状増殖で，各細胞間の異型や mitosis のないもの, grade II は各細胞間に軽度の異型があり， 特に giant-cell もみられるが， mitosis はあつても軽度 で浸潤性発育も軽く，全体的に軽度の変化を呈するも の, grade III grade II にみられた変化の強いもので, 時に扁平上皮化のあるもの，grade IVは未分化癌とし た。

stage も I からIVに分類したが, stage 1 は非浸潤性の 腫瘍, stage II は表在性の浸潤のみられるもの, stage III は腎孟筋層または腎実質へ浸潤するもの， stage IVは腎 孟外膜または腎被膜をこえているもので，とさにリンパ 節あるいは隣接臓器に浸潤するものとした。17例を上述 の組織学的 grade でみると grade Iは 1 例, grade II は7例, grade III 8 例, grade IVは 1 例であつた。 た stage をみると, stage Iは 2 例， stage II は8例， stage III 4 例, stage IVは 3 例であつたが, grade と stage との間にはよい相関々係がみられた。

10. 転帰

腎盂移行上皮癌21例の転帰をみると図 1 のごとくであ る.な扮生存率は, 1963年 international symposium on end result of cancer therapy で採用された計算法に準じ て，実測生存率をむとめた。 21 例の 1 年生存率は $76 \%$, 3 年生存率は $69 \%, 5$ 年生存率は $60 \%$ であつた。

つぎに stage および grade と生存率との関係をみる と, high stage (stage III 拈よびIV) 7 例中 4 例は 1 年 以内に死亡しており，5年以上の生存例は 1 例のみであ る.これに対し low stage (stage I およびII)では, 10 例中死亡例は 2 例のみで， 5 例は 5 年以上生存してい る。また high grade (grade III およびIV) 9 例中 4 例は 1 年以内に死亡し， 5 年以上生存例は 3 例であるのに対 
図 1 腎孟移行上皮癌21例の実測生存率

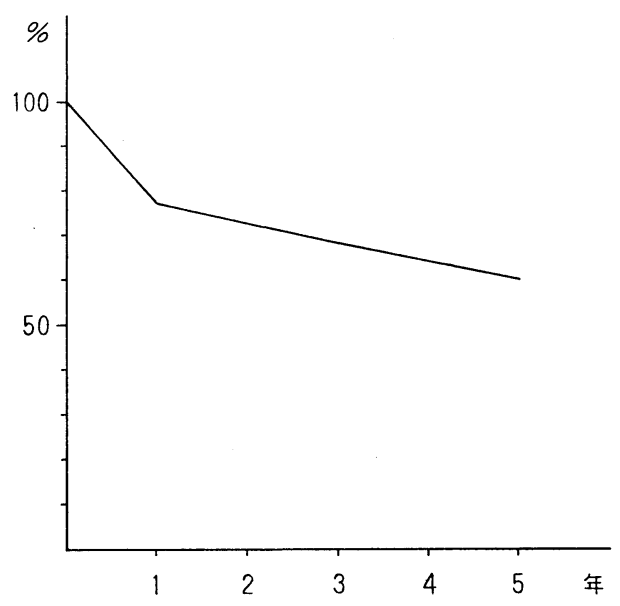

し, low grade (grade I および II) 8 例では 1 年以内の 死亡は 1 例のみで, 3 例が 5 年以上生存している.

腫大した腎腫瘤を触知した 2 例はいずれも 1 年以内に 死亡しており，排泄性腎盘造影で無造影であつた2例 は, 術後 7 力月拉よび 4 年 1 力月で死亡している. 初診 時尿管腫瘍, 膀胱腫瘍を併発していた 5 例についてみる と, 4 例は術後 6 力月, 7 力月, 2 年 5 力月, 4 年 7 力 月で死亡して拈り，1 例のみが術後 7 年の現在再発なく 健在である. 一方腎㙉扁平上皮癌の 2 例はいづれも 1 年 以内に死亡した。

\section{総括ならびに考察}

腎盘腫瘍は腎細胞癌と同様に男子に多くみられる. そ

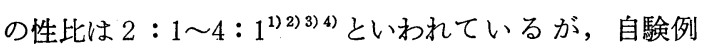
では男子は女子の約6.7倍であつた，患側は自験例のよ らに左側に多い(1)5) とも，また逆に右側に多い(6)7〕い われているが，これらの報告をあわせてみると，左右差 はないよらである，年齢は50歳台および60歳台に最も多 くみられるが，性別による発生年齡の差は認められな 认.

初発症状としては，肉腿的血尿が $87 \%$ と圧倒的に多か つたが，これは腎血内腫瘍表面の潰瘍化あるいは壊死が 比較的早く生じ, 腎細胞癌にくらべてより早期に血尿が

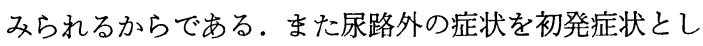
たものは 2 例のみで，腎細胞癌礼に比べ少なかつた。

臨床症状としても最も多いのも血尿で, Riches ${ }^{1)}$ は血 尿を唯一の症状としたもの $49 \%$, 疼痛を伴なつたもの 40 \%と約 $90 \%$ に血尿を認めて扣り，Williams ${ }^{9)}$ も43例中 36 例， $84 \%$ に血尿があつたという. 自験例でも腎血扁平上
皮癌 2 例中 1 例に血尿を認めなかつたが, 移行上皮癌 21 例は全例肉眼的血尿を訴えており，血尿は腎盂移行上皮 癌ではまず必発の症状といつてよい。

疼痛は 2 番目に多い症状で，8例，35\%にみられた が， Riches ${ }^{1)}$ も172例中77例，45\%に認めている. 疼痛 は大部分鈍痛であるが，血塊が尿管を通過する時に疝痛 様発作を生ずることがある. 自験例では疝痛は 8 例中 2 例，25\%にみられ，その頻度は腎細胞癌8)より多いが， 2 例とも著しい血尿を伴なつており，凝血の排出により 軽快している。

腎腫瘤の触知は腎細胞癌に比べて少なく，1.8\% ${ }^{1)}$ か ら $16 \%$ にみられるといら，自験例で腫瘤を触知したも のは 4 例， $17 \%$ であが，ちち 2 例は腎血扁平上皮癌で あり, 移行上皮癌の 2 例は, 併発した尿管腫瘍により巨 大水腎症を呈したものであつた。すなわち腎血移行上皮 癌では, 腫瘍そのものが増大し, 腫瘤として触知可能に なることは稀であり，時に水腎症となつてふれることが ある。

尿路外の全身症状は8例にみられた．発熱は 2 例に認 めたが，1 例は疗路感染を伴なつていた．胃腸症状は 4 例にみられたが，これについて Higgins ${ }^{10)}$ は，腎および 腸を支配している交感神経, 副交感神経の密接な関連に よるものと説明している.

腎細胞癌では, 転移のないのに肝機能障害を生ずる例 がみられるが11), 腎血腫瘍での報告はない. 自験例でも 肝機能障害の明らかなものはなかつたが, 腎肉腫, 黄 色肉芽腫様腎需炎でも肝機能障害例が報告されて拉 $\eta^{12)}{ }^{13)}$ ，腎血腫瘍に肝機能障害が伴ならこともありらる であろう。

高カルシウム血症がみられたのは腎結石を伴ない, 骨 転移の疑われた腎盘扁平上皮癌 1 例のみで, 移行上皮癌 の血清カルシウム值はすべて正常であつた．しかし悪性 腫瘍の $10 \%$, 全経過中のいずれかの時期に高カルシウ ム血症をみるといわれて拈り ${ }^{14)}$ ，また転移のない腎血腫 瘍で高カルシウム血症の認められた報告もあり ${ }^{15)}$, 本症 にも腎細胞癌と同様に高カルシウム血症は発生しらると 思われる。

腎結石を伴なつた腎孟扁平上皮癌 2 例は尿路感染が認 められており，扸瘍はこれらの慢性刺激により，2次的 に発生したものと考兄られる.一方移行上皮癌21例中， 尿路感染のみられたものは，カテーテル留置の施行され た 1 例のみであつた。しかし尿路の閉塞をおこすと腎感 染が生じ易く，腎孟腫瘍で腎血腎炎による発熱が著明に 
なることがある。

腎盎腫渲の尿中細胞診の陽性率について, Sarnacki ${ }^{16)}$ は $59 \%, \mathrm{Grace}^{6)}$ は33\%といつているが, 自験例では 8 例中 3 例, $38 \%$ に陽性であつた. Say ${ }^{17)}$ は腎盂移行上皮 癌 4 例中診断できたのは 1 例の みであり, Cummings ${ }^{2)}$ は 9 例に行ない 2 例は診断出来, 7 例は suggestive にと ぞまつたという．徳中 ${ }^{18)}$ は上部尿路上皮腫瘍の尿沈渣の Papanicolaou 検查で, 7 例の high grade の腫瘍中 6 例 は陽性であつたが, low grade の 2 例では陰性であつた という。また Gill19) は, blushing technique を用い診 断的正確度を向上させたとのべている.

Cummings $^{2)}$ は, high grade の腫瘍は, 腎孟からの barbotaged specimens により, 病理学者は容易に識別出 来, low grade の細胞診では腫瘍細胞の細胞塊が大いに 価值があるといつている. しかし尿沈渣の塗抹標本では 原型を保持している細胞をみることが少ないため, 確定 診断をくだすのは危険なこともあると思われる。

腹部単純撮影で軟部腫瘤を認めたものは, 腎孟移行上 皮癌 21 例中 2 例, $9.5 \%$ で, 腎細胞癌の $59 \%{ }^{20)}$ 飞比して 少ない。この 2 例はいずれも巨大な水腎症を呈したもの である.また結石は 3 例に認めた。腎㙉腫愓の結石合併 頻度は約 $10 \%{ }^{21)}$ といわれるが, 組織別にみると扁平上 皮癌に圧倒的飞多い，本邦に打ける扁平上皮癌87例で

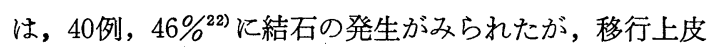
癌では235例中 12 例, $5.1 \%{ }^{21)}$ で, 自験例も 21 例中 1 例, $4.8 \%$ と同様であつた。

腎孟腫瘍の腎孟造影による主要所見は腎孟腎杯の充満 欠損である ${ }^{20)}$. Cummings ${ }^{2)}$ は排泄性腎孟造影で，35例 中15例に充満欠損を認めており, 逆行性腎孟造影を行な つた30例のうち29例に腎孟の病変を明らかにし得たとい ら。また Williams ${ }^{9)}$ は，排泄性腎孟造影を施行した 37 例全例に腎孟像の变化を認め, このうち結石を合併した 2 例を含めて28例は腫瘍と診断し得たという．自験例で も排泄性腎盂造影で, 23例中無造影の 4 例を除いた19例 に腎㙉腎杯の充満欠損を認め, 診断上有用であつた。乙 かし腎盂移行上皮癌が腎㙉内へ突隆せず，腎実質内に浸 潤する例では，腎盂造影で全く变化をみないことがあ $る^{28)}$.

腎の無造影は腎㙉移行上皮癌の15～42\% 2) 17) にみられ るといらが, 自験例では21例中 2 例, $10 \%$ に認められ た。また無造影は high grade, high stage のものに多い との報告があるが, 自験例 2 例はいずれも併発した尿管 腫瘍のため高度の水腎症を呈したもので, grade はI お
よびIIであつた．したがつて，併発腫湟のない腎盖移行 上皮癌で無造影になる頻度はさらに少ないと思われる。

腎血管造影は本症の診断上意義があり, Rabinowitz ${ }^{24)}$ は22例中12例飞腎孟尿管動脈の拡大を，16例血管狭窄 を認め，また血管新生は18例にみている．腎孟腫瘍の血 管造影での重要所見は，腎孟尿管動脈の拡大と腎動脈の 狭窄であり, 自験例では, 11 例中動脈拡大 3 例之血管狭 窄 6 例の計 9 例が認められた。一方腎細胞癌では全例に みられた血管新生は，腎孟腫瘍では11例中 6 例に細かい 異常血管を認めたのみで，5例にはみられなかつた。す なわち腎孟移行上皮癌では, 腫瘍が腎孟内の小腫瘍とし てとどまる時には正常動脈像を呈し, 腎実質に浸潤して はじめて細かい血管新生がみられた。

腎盂移行上皮癌の特徵の 1 つとして, 尿路の他の部位 飞も同じ移行上皮性の腫瘍が発生することがあり, 自験 例では 21 例中 8 例, $38 \%$ に尿管腫瘍または膀胱腫瘍の発 生をみている. O'conor ${ }^{25)}$ は27\%に尿管腫瘍の併発をみ て括り, Greene ${ }^{26)}$ は26例の上部尿路腫湟の $34 \%$ は多発 性の腫瘍を有していたという。

また Johnson ${ }^{3)}$ は腎孟移行上皮癌49例中22例に膀脂腫 瘍の発生をみているが，これを時期的にみると，5例は 膀胱腫瘍の既住があり，2 例は腎盂腫瘍の検査中に発見 され，13例は術後の経過観察中に発生したものである. Williams s) 女腎盂腫瘍の診断時に膀胱腫瘍が併発したる のは，43例中 3 例にすぎなかつたが，のこり 40 例中 17 例 は術後に膀胱腫瘍が発生したといら。これら腎典腫瘍の 治療から膀胱腫瘍の発生まで平均期間は 15 月 2 年 で, 大部分は 3 年以内に発生している3 ${ }^{39)}$. したがつて われわれは腎孟腫崵の手術後, 定期的な膀胼鏡検査を最 初の 3 年間は 3 カ月毎に行ない, 次の 2 年間は 6 カ月毎 に，その後は 1 年毎に行なうようにしている.

腎盂腫瘍, 特に移行上皮癌の手術々式としては, 尿管 口周辺の膀胱壁を含めた腎尿管全摘除術が必要とされて いる.これは腎㙉移行上皮癌には尿管腫瘍の併発が高頻 度にみられること, および遺残尿管に腫瘍が発生するか らであり，自験例でも1954年以前の 3 例をのぞいた腎孟 移行上皮癌18例中 17 例に腎拉よび全尿管を摘除してい る. 尿管断端の腫湟の発生率は12 33\% (1)3) 25) といわれ ているが, Taylor ${ }^{7)}$ は腎尿管全摘除を行なつた13例中再 発例は, 膀胱腫瘍の 2 例の $15.4 \%$ で, 単に腎摘除を施行 した場合の尿管および膀胖腫瘍の再発率33\%よりすぐれ ているとのべている.

つぎに尿管口部の膀胱壁の切除について, Williams ${ }^{9}$ 
は膀脱壁まで切除した 17 例では 5 例に, 切除しなかつた 20例では12例に膀腅腫場が発生していること,さらにこ れらの膀胖腫瘍17例中，12例は尿管口の附近にみられて おり，尿管摘出時に膀胱壁を含めて摘除することが大切 とのべている.

一方高井 ${ }^{27)}$ は腎孟腫煌 17 例について, 腎尿管摘除例 5

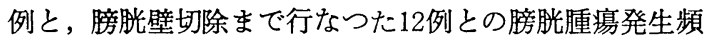
度を比較し，両者に差がなかつたといつている．自験例 では両群に各 1 例膀胼腫瑒が発生しているが，いずれも 尿管口とは関係のない位固であつた．この点については 今後さらに症例を增やして検討する予定であるが，いら゙ れにせ上術後定期的な膀脱鏡検查を行ない，再発腫湯の 早期発見および治療を行ならことが大切と考兵る.

一方腎孟扁平上皮癌の手術方法は, 本症が移行上皮癌 と異なり尿管膀脱を侵襲する傾向が少ないので, 上部尿 管とともに腎摘除を行なえば十分と考える。

腎孟腫瘍に対する放射線療法拈よび化学療法は一般的 には効果が期待できないといわれており，自験例でも明 らかな有効例は認められなかつた。

腎盂移行上皮癌の予後は, 腎細胞癌よりも不良で, 5 年生存率は $35 \%$ ～43\% ${ }^{117)}$ といわれている.

自験例 21 例の 5 年生存率は60\%で, 腎細胞癌81例の 5 年生存率 $47 \%^{8)}$ より良好であつた。

予後に関与する大きな因子としては, 腫場細胞の悪性 度と, 浸潤度があげられる。

Cummings ${ }^{2)}$ は high grade $と$ high stage の症例は， 手術々式に拘らず予後が不良であつたが, low grade と low stage の症例は，尿管を完全に摘出すれば良好な転 帰が得られたといら. Johnson ${ }^{3)}$ 子腫瘍の grade あるい は invasion の程度と生存率との間には, 正の相関々係 があり, lymphatic permeation, vascular invation, 腎実 質への浸潤のみられるものは予後が不良であつたとのべ ている. 自験例でも, high grade 拈よび high stage の 転帰は不良であつたが, 特に浸潤度と予後は密接な関係 がみられた。

Becker ${ }^{28)}$ は 5 例の無機能腎であつた症例を報告し， 予後が不良であつたという．また Say ${ }^{17)}$ は腎腫瘤を触 知したものの予後は病理学的診断にかかわらず不良であ るといい, Higgins ${ }^{10)}$ も同様の報告をしている。 しか し，Williams”) は腫大した腎を触知し得た 7 例の予後 は，特に悪くなかつたといつている．自験例21例の腎盂 移行上皮癌では，3例が腎腫瘤を触知したりあるいは無 造影であつたが，いずれる 1 カ月， 6 カ月， 4 年 1 カ月
で死亡している。しかし 3 例とも low grade で, 同時 に発生した尿管腫瘍のために水腎症をさたしたものであ り,これら尿管腫瘍を伴なら腎皿移行上皮癌の予後は, 併発した尿管腫瘍のひろがりによつても規定されるよう である. Riches ${ }^{1)}$ む尿管, 膀胱に腫場の併発した例の子 後は不良であるといつている.

一方腎盂扁平上皮癌 2 例もいずれも 1 年以内に死亡し ているが，その予後は甚だ不良である. 本邦に和ける54 例中 35 例, $65 \%$ は術後 6 カ月以内に死亡しており，1 年 以上生存したものは 6 例，11\%にすぎない。 5 年生存 例はいまたみられず， 3 年生存例が 1 例あるのみであ $ð^{22)}$.

\section{結 語}

慈恵医大附属病院で経験した腎孟腫瘍23例についてそ の臨床的観察を行なつた。

1） 23 例中腎盂移行上皮癌は 21 例， $91 \%$, 扁平上皮癌 は 2 例であつた。

2）患側は左に多く，男子は女子の 6.7 倍で，平均年 龄は59歳であつた。

3）初発症状は肉眼的血尿が 20 例， $87 \%$ と最も多く, ついで疼痛の 3 例であつた.

4）臨床症状としては肉眼的血尿が 22 例，96\%と最も 多く, 疼痛 8 例, $35 \%$, 腫瘤 4 例の順であつた。胃腸症 状などの尿路外症状は 8 例, $35 \%$ に認められた。

5）臨床検査では貧血が 7 例， $30 \%$ に, 赤沈克進は 10 例，43\%にみられ， $\alpha_{2}$-globulin は6 例， $38 \%$ に上昇し ていた。しかし肝機能障害例や高カルシウム血症はみら れなかつた。

6）尿中細胞診は 8 例中 3 例， $38 \%$ に陽性であつた。

7）腎部単純撮影で結石の合併は 3 例に, 軟部腫瘤は 4 例にみられた。排泄性腎孟造影では19例，83\%に腎孟 腎杯の充満欠損を認め，4例は無造影であつた。腎血管 造影を行なつた11例では, 腎動脈の狭窄を 6 例, 腎孟尿 管動脈の拡大を 3 例に認め, 血管新生は 5 例にみられ た.

8）腎孟移行上皮癌 21 例中 8 例，38\%は尿管，または 膀脱にも腫瘍の発生をみた。

9） 23例中17例は腎尿管摘除術を行なつたがが，この らち13例は尿管口周辺の膀胖壁の一部を含め摘出した。 初期の例拉よび腎需扁平上皮癌などの 6 例は腎摘除の及 を行なつた。

10）腎盂移行上皮癌 21 例の 5 年生存率は $60 \%$ であり， 組織学的 grade と stage は予後と密接な関係がみられ 
た。また尿管や膀脂に腫瘍を併発した症例の予後は不良 であつた. 腎盂扁平上皮癌 2 例はいずれも 1 年以内に死 亡した。

\section{文献}

1) Riches, E.W., Griffiths, I.H. and Thackray, A.C.: Brit. J. Urol., 23, 297, 1951.

2) Cummings, K.B., Correa, R.J., Jr., Gibbons, R.P., Stoll, H.M., Wheellis, R.F. and Mason, J.T.: J. Urol., 113, 158, 1975.

3) Johnson, D.E., de Berardinis, M. and Ayala, A.G.: South. med. Journal., 67, 1183, 1974.

4) Grabstald, H., Whitmore, W.F. and Melamed, M.R.: JAMA., 218, 845, 1971.

5) McDonald, J.R. and Priestley, J.T.: J. Urol., 51, 245, 1944.

6) Grace, D.A., Taylor, W.N., Taylor, J.N. and Winter, C.C.: J. Urol., 98, 566, 1967.

7) Taylor, W.N.: J. Urol., 82, 452, 1959.

8）南武, 增田富士男, 佐々木忠正: 日泌尿会 誌, 66, 474, 1975.

9) Williams, C.B. and Mitchell, J.P.: Brit. J. Urol., 45, 370, 1973.

10) Higgins, C.C.: Ann. Surg., 137, 195, 1953.

11）增田富士男, 佐々木忠正, 渡辺秀雄, 荒井由和, 町田豊平：泌尿紀要, 22, 91, 1976.

12) Summerskill, W.H.J. and Shorter, R.G.: Arch. Intern. Med., 120, 81, 1967.

13 Vermillion, S.E., Morlock, C.G., Bartholomew, L.G. and Kelalis, P.P.: Ann. Surg., 171, 130, 1970.

14) Myers, W.P.L.: Cancer., 9, 1135, 1956.
15）折茂 肇, 中尾純子, 亀山正邦, 杉浦昌也, 蔵 本 筑, 上田度二, 東儀英二, 福島保喜, 金沢 暁太郎, 中内浩二, 島田譬, 嶋田裕之, 白木 正孝, 稲松孝思, 新美範之: Nikkei Medical, 2, 76, 1975.

16) Sarnacki, C.T., McCormack, L.J., Kiser, W.S., Hazard, J.B., McLaughlin, T.C. and Belovich, D.M.: J. Urol., 106, 761, 1971.

17) Say, C.C. and Hori, J.M.: J. urol., 112, 438, 1974.

18）德中荘平, 広田紀昭, 辻一郎：西日泌尿, 38, 681, 1976.

19) Gill, W.B., Lu, C.T. and Thomsen, S.: J. Urol., 109, 573, 1973.

20）多田信平，兼平千裕，增田富士男，町田豊平： 臨泌, 30, 571, 1976.

21）岡 道基：西日泌尿, $35,330,1973$.

22）增田富士男, 工藤 潔, 佐々木忠正, 町田豊平: 臨泌，30, 91，1976.

23) Utz, D.C. and McDonald, J.R.: J. Urol., 78, 540, 1957.

24) Rabinowitz, J.G., Kinkhabwala, M., Himmelfarb, E., Robinson, T., Becker, J.A., Bosniak, M. and Madayag, M.M.: Diagnostic Radiology., 102, 551, 1972.

25) O'conor, V.J.: J. Urol., 75, 416, 1956.

26) Greene, L.B., Hayllar, B.L. and Bogash, M.: J. Urol., 79, 697, 1958.

27) 高井修道: ·日泌尿会誌, 64, 685, 1973.

28) Becker, J.A.: J. Urol., 101, 280, 1969.

(1977年 2 月 2 日受付) 